\title{
Free proline, soluble sugars and soluble proteins concentration as affected by salt stress in two sugarcane (Saccharum sp.) cultivars differing in their salt tolerance
}

\author{
Christophe Bernard GANDONOU ${ }^{1,2, *}$, Fidèle BADA ${ }^{2}$, Jamal ABRINI ${ }^{1}$ and \\ Nadia SKALI-SENHAJI ${ }^{1}$ \\ ${ }^{1}$ Laboratoire de Biologie et Santé, Université Abdelmalek Essaâdi, Faculté des Sciences de Tétouan, \\ B.P. 2121 Tétouan, Maroc. \\ ${ }^{2}$ Laboratoire de Physiologie Végétale, Faculté des Sciences et Techniques (FAST/UAC), 01BP 526 Cotonou, \\ République du Bénin. \\ *Corresponding author; E-mail: ganchrist@hotmail.com; Tel. (00229) 97396978.
}

\begin{abstract}
Salt stress is one of the environmental stresses which affect negatively the agricultural production of the world. In this study, the effects of salt stress on free proline, soluble sugars and soluble proteins accumulation were investigated in two sugarcane (Saccharum sp.) cultivars: CP66-346 (salt-tolerant) and CP65-357 (salt-sensitive). Young plants of these cultivars were exposed, in a hydroponic system, to four concentrations of $\mathrm{NaCl}(0,17,34$ and $68 \mathrm{mM})$. These concentrations correspond to an electric conductivity of 1; $2.83 ; 4.26$ and $6.63 \mathrm{mS} / \mathrm{cm}$, respectively. Free proline, soluble sugars and proteins accumulation were quantified after 2 weeks of stress. Proline and soluble sugars concentrations increased significantly in leaves and roots under salinity. Furthermore, $\mathrm{NaCl}$ caused an increase in soluble proteins concentration in leaves and roots of the tolerant cultivar CP66-346 and a decrease in leaves and roots of the sensitive CP65-357. Salttolerant CP66-346 plants accumulated more soluble sugars in leaves than CP65-357, while both cultivars accumulated similar quantities of proline in leaves. These results provided evidence that soluble sugars could contribute mainly to counteract the negative water potential of the outside medium and that protein synthesis stimulation was implicated in sugarcane salt tolerance. Proline appeared as a symptom in salt-stressed sugarcane plants rather than as an indicator of tolerance
\end{abstract}

(c) 2011 International Formulae Group. All rights reserved.

Keywords: Sugarcane, Saccharum sp., proline, soluble sugars, soluble proteins, salt-tolerance.

\section{INTRODUCTION}

Salinity is a major environmental factor limiting the crop productivity in the arid and semi-arid areas of the world (Dasgan et al., 2002). This complex abiotic stress, which affects osmotic and ionic components, poses a threat to agriculture (Munns et al., 2006). It induces a wide range of metabolic perturbations in higher plants; but it is not always possible to distinguish the perturbations associated with the osmotic component from those due to ion toxicity. 
These metabolic perturbations result in growth reduction and alteration of nutritional balance. However, in order to survive in the presence of salt, plants have developed several adaptative mechanisms that are not yet well established (Lutts et al., 1996) and there is a substantial variation in salt-tolerance among different species (Munns et al., 2002) and among cultivars of the same species (AlKaraki, 2000; Ghoulam et al., 2002). Proline accumulation is frequently reported in plant confronted with salt stress (Shafi et al., 2011); however, its physiological significance is still not well-understood. Most usually, it was considered to act as a compatible osmoticum and therefore to be involved in salt resistance mechanisms (Ehsanpour and Fatahian, 2003; Sakhanokho and Kelley, 2009). However, proline could be just a sign of stress as reported by Gandonou et al. (2005) and Prajuabmon et al. (2009). Salt stress usually results to soluble sugars increase (Watanabe et al., 2000). These solutes seemed also to be involved in osmotic adjustment. Tolerant varieties always accumulate more soluble sugars in leaves and growing tissue than sensitive ones (Watanabe et al., 2000). Soluble proteins concentration is reduced under salt stress and this reduction is related to the inhibition of their synthesis or the stimulation of their hydrolysis (Irigoyen et al., 1992). Contrary to other glycophytes such as rice, corn and wheat, little is known about the physiological mechanisms involved in sugarcane salt tolerance. Sugarcane plant is considered as moderately sensitive to salinity (Maas and Hoffmann, 1990); some studies analyzed salt effects on plant growth and metabolism (Rozeff, 1995; Lingle et al., 2000), without, however, highlighting the physiological mechanisms implied in salt tolerance.

In the present study, we compared $\mathrm{NaCl}$ effects on proline, soluble sugars and soluble proteins accumulation in leaves and roots of plants of two sugarcane cultivars which differ in their response to salt stress. Our aim in this study was to analyse the implication of organic solutes accumulation in sugarcane plant salt tolerance.

\section{MATERIALS AND METHODS}

\section{Plant material and culture conditions}

Sugarcane (Saccharum sp.) cultivars are obtained from the "Centre Technique des Cultures Sucrières" (CTCS), Morocco. CP65357 and CP66-346 are American cultivars (Canal Point) largely cultivated in Morocco. According to our previous report, CP66-346 is more salt tolerant than CP65-357 at whole plant level (Gandonou et al., 2011b). Stalk segments were cut in single bud sets (approximately $5 \mathrm{~cm}$ ), surface disinfected with ethanol $70 \%$, placed between humidified journal papers and transferred in drying oven at $30{ }^{\circ} \mathrm{C}$ for germination. After 6 to 8 days, plants were transferred to pots containing tap water for 8 days in culture room characterized by a temperature of $28 \pm 2{ }^{\circ} \mathrm{C}$, a photoperiod of $14 \mathrm{~h} / 10 \mathrm{~h}$, light intensity between 1100 and 1200 lux with artificial lamps, brand Philips, TL 40 w/54-765 and a relative humidity of $50 \%$. Then, tap water was replaced by modified Hoagland solution (Hoagland and Arnon, 1950) in which macro-elements concentrations have been reduced to half and added with Fe-EDTA of Murashige and Skoog (1962). The medium was prepared with distilled water and $\mathrm{pH}$ was adjusted to 6.5 with concentrated $\mathrm{NaOH}$. Plants were cultivated in this medium for 7 days.

\section{Salt treatment}

After these 7 days in culture, stress was applied to the plants, three $\mathrm{NaCl}$ concentrations were used: 17; 34 and $68 \mathrm{mM}$ corresponding respectively to an electric conductivity of $2.83 ; 4.26$ and $6.63 \mathrm{mS} / \mathrm{cm}$. The control corresponds to an electric conductivity of approximately $1 \mathrm{mS} / \mathrm{cm}$. 
Electric conductivities were adjusted every two days with a conductivity meter (Model 4150 Brand Jenway, UK) when water was reduced by evapo-transpiration. Each pot contains 10 plants and $2-3$ pots per $\mathrm{NaCl}$ concentration were used. Stress was maintained for 2 weeks.

\section{Extraction and soluble solutes determination}

Soluble proline extraction and determination were done as reported in our previous paper (Gandonou et al., 2005). 100 $\mathrm{mg}$ of leaves (youngest fully expanded leaf) and roots were used. Proline was quantified spectrophotometrically $(515 \mathrm{~nm})$ and expressed on fresh matter basis. L-proline was used as standard.

For soluble sugars determination, methods published by Watanabe et al. (2000) and used in our previous report (Gandonou et al., 2006) were used. The youngest fully expanded leaf and roots were used. Soluble sugars were quantified spectrophotometrically $(620 \mathrm{~nm})$ and expressed on fresh matter basis.

As far as soluble proteins determination was concerned, the method reported in our previous paper (Gandonou et al., 2011a) was used. The youngest fully expanded leaf and roots were used. Soluble proteins were quantified spectrophotometrically $(595 \mathrm{~nm})$ and expressed on fresh matter basis.

\section{Statistical analysis}

All the experiments were repeated twice independently with similar results. Data are expressed as mean \pm standard error with a reading of three or four samples per treatment. The analysis of the main effects of stress intensity and/or cultivars was based on a 1way or 2 ways analysis of variance (ANOVA). All statistical analyses were performed by SAS 92 program (SAS Institute, 1992).

\section{RESULTS \\ Free proline accumulation}

In the presence of $\mathrm{NaCl}$, free proline concentration increased significantly in roots $(p<0.01$, Table 2$)$ and in leaves $(p<0.05)$ in both sugarcane cultivars (Figures 1a, b). Statistical analysis revealed a significant difference between cultivars only for roots proline content (Table 1). These results indicate that both cultivars accumulated the same amount of proline in leaves and that the salt-sensitive CP65-367 accumulated more proline in roots than the salt-tolerant CP66346.

\section{Soluble sugars accumulation}

$\mathrm{NaCl}$ caused a dose dependent increase in soluble sugars content in leaves of the salt-tolerant CP66-346 and in roots of saltsensitive CP65-357 (Figures. 2a, b). Statistical analysis revealed a significant effect of $\mathrm{NaCl}$ concentration only in roots $(\mathrm{p}<0.01$, Table 1). However, this analysis revealed a significant difference between varieties for leaves $(\mathrm{p}<0.001$, Table 1$)$ and roots $(\mathrm{p}<0.05$, Table 1$)$ soluble sugars content. It appears that salt-tolerant cultivar accumulated more soluble sugars in leaves than the salt-sensitive one, especially at the higher $\mathrm{NaCl}$ concentrations. An opposite tendency was observed for roots.

\section{Soluble proteins accumulation}

Soluble proteins concentration decreased significantly in leaves $(p<0.05$, Table 2) and none significantly in roots of the salt-sensitive CP65-357 while a non significant increased was observed in leaves and roots of the salt tolerant CP66-346 in the presence of $\mathrm{NaCl}$ (Figures. 3a, b) as shown by a one-way ANOVA (Table 2). 
a) Leaves

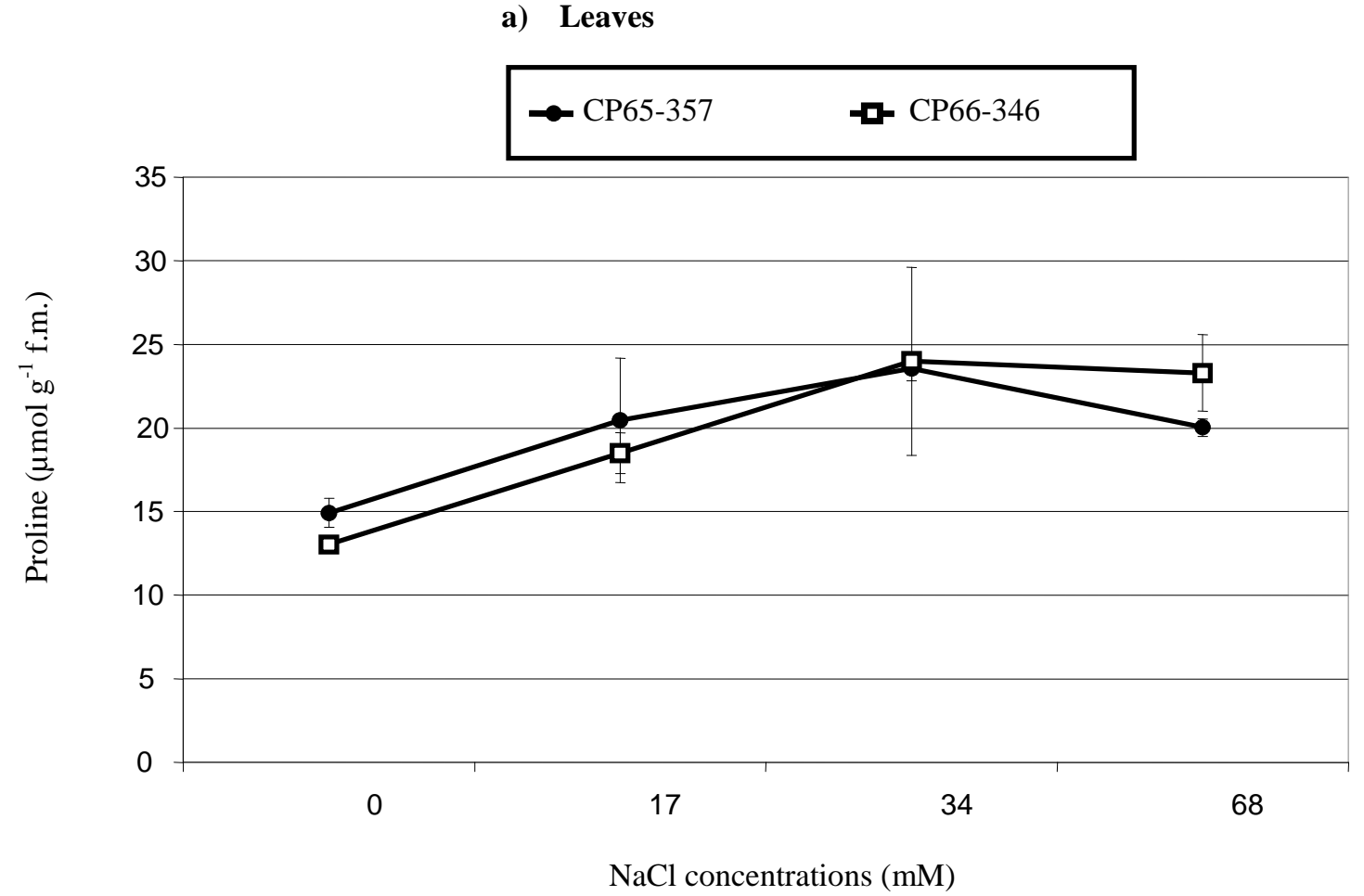

2444 
b) Roots

(b)

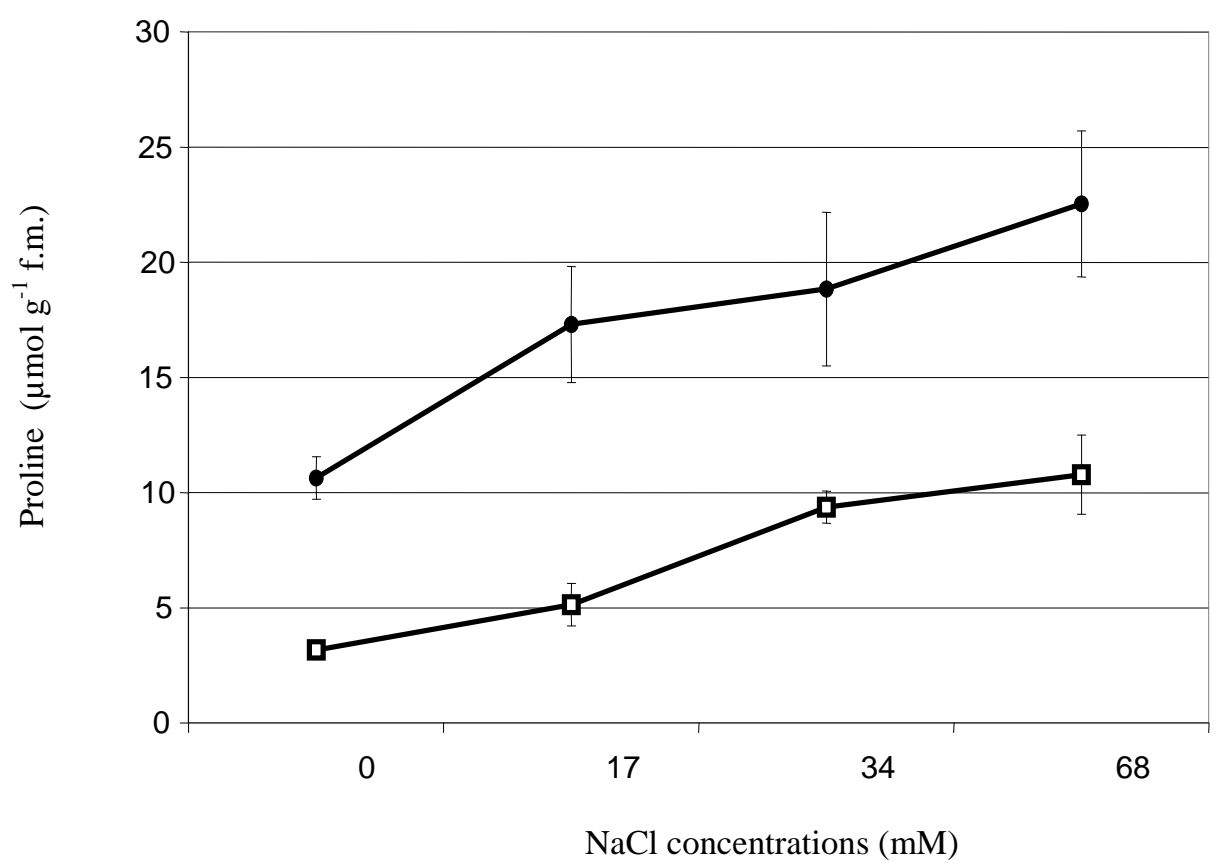

Figure 1: Proline concentration [in $\mu \mathrm{mol} \mathrm{g}{ }^{-1}$ (f. m.)] in leaves (a) and in roots (b) of two sugarcane cultivars (CP65-357, salt-sensitive and CP66-346, salt-tolerant) as affected by different concentrations of $\mathrm{NaCl}$ after 2 weeks ( $n=3$; vertical bars are S.E.).

f. $\mathrm{m} .=$ Fresh matter. 
C. B. GANDONOU et al. / Int. J. Biol. Chem. Sci. 5(6): 2441-2453, 2011

a) Leaves

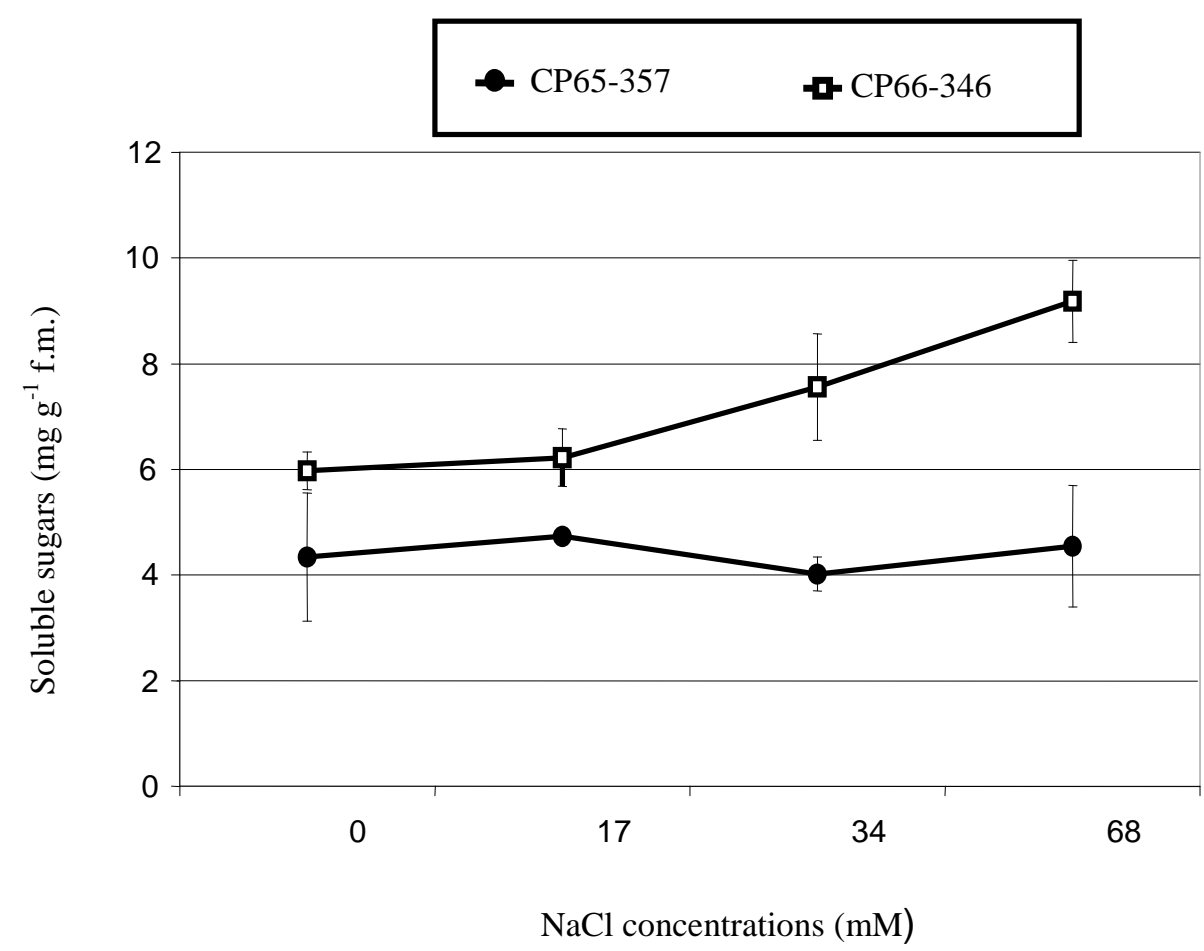

2446 


\section{b) Roots}

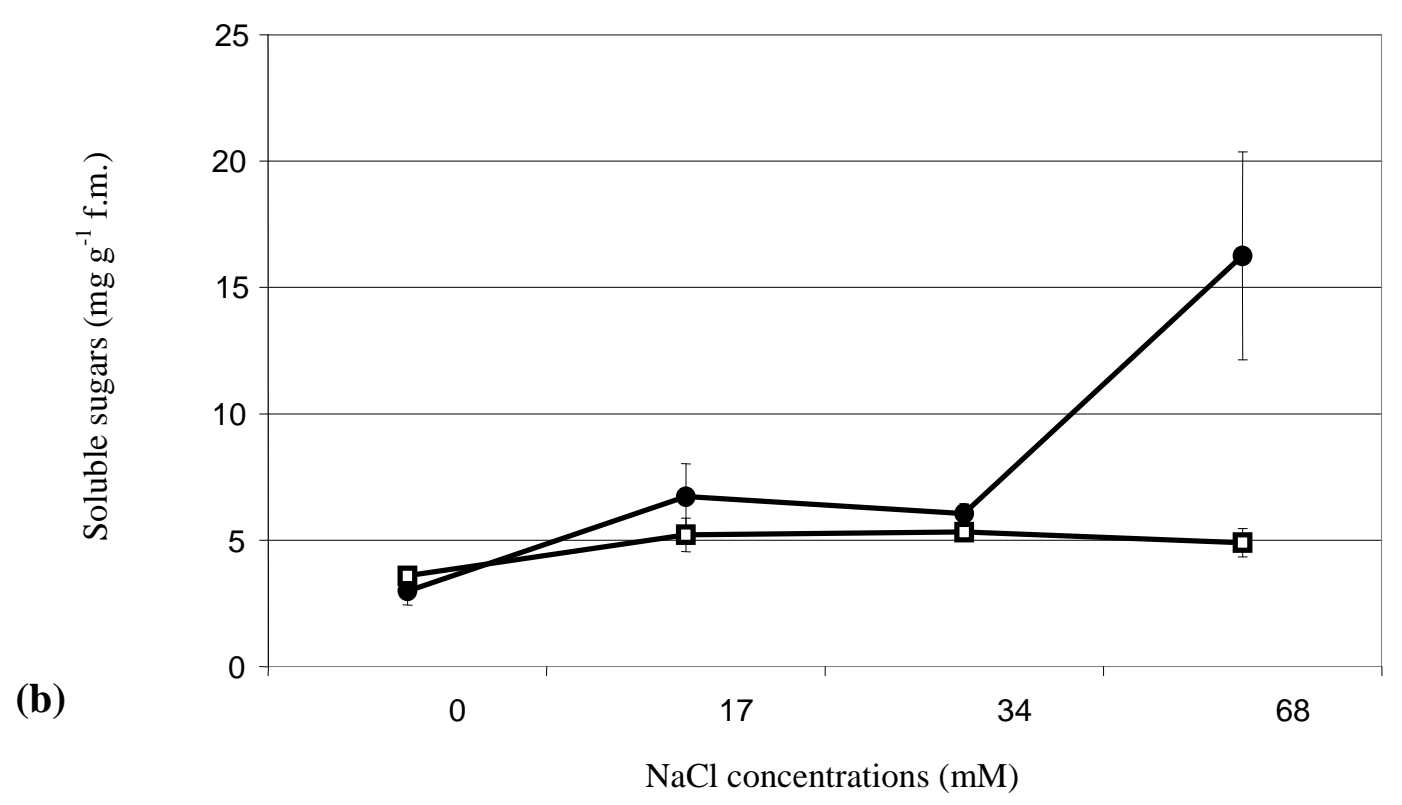

Figure 2: Soluble sugars concentration [in $\mu \mathrm{mol} \mathrm{g}^{-1}$ (f. m.)] in leaves (a) and in roots (b) of two sugarcane cultivars (CP65-357, salt-sensitive and CP66-346, salt-tolerant) as affected by different concentrations of $\mathrm{NaCl}$ after 2 weeks ( $\mathrm{n}=3$; vertical bars are S.E.).

f. $\mathrm{m} .=$ Fresh matter. 
C. B. GANDONOU et al. / Int. J. Biol. Chem. Sci. 5(6): 2441-2453, 2011

\section{a) Leaves}

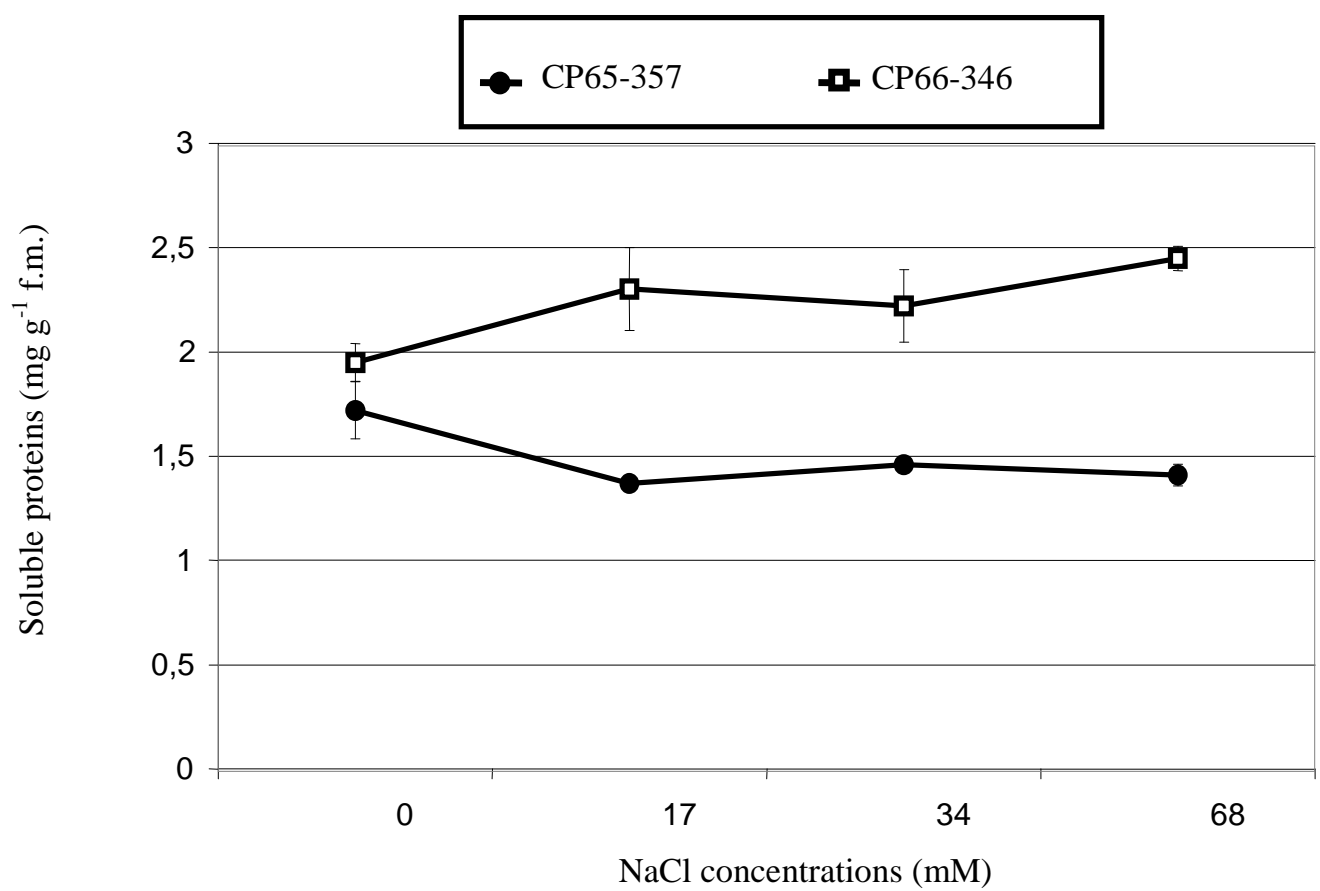

2448 


\section{b) Roots}

(b)

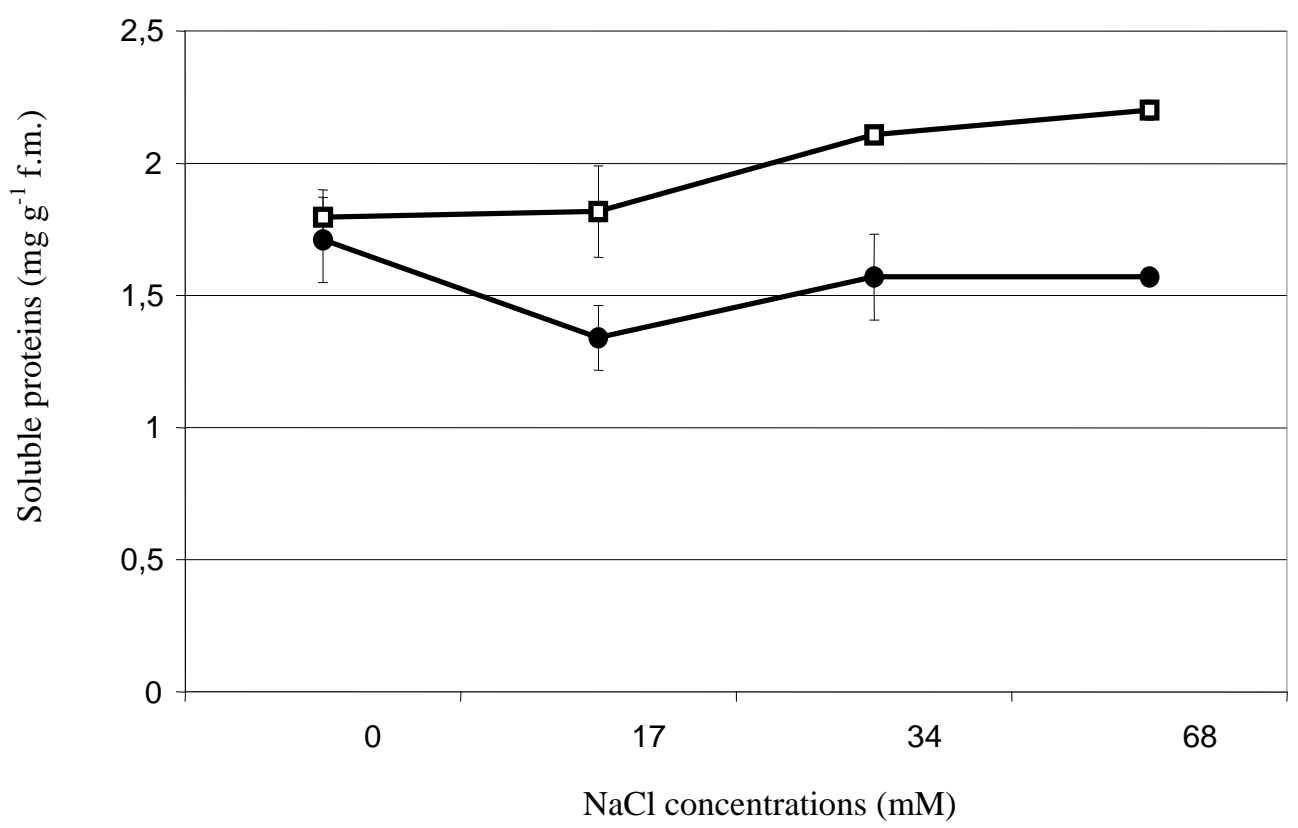

Figure 3: Soluble proteins concentration [in $\mathrm{mg} \mathrm{g}^{-1}$ (f. m.)] in leaves (a) and in roots (b) of two sugarcane cultivars (CP65-357, salt-sensitive and CP66-346, salt-tolerant) as affected by different concentrations of $\mathrm{NaCl}$ after 2 weeks ( $\mathrm{n}=3$; vertical bars are S.E.).

f. m. = Fresh matter. 
Table 1: Results of 2-ways analysis of variance of proline and soluble sugars accumulation in leaves and roots of sugarcane plants.

\begin{tabular}{lcccc}
\hline Parameters & Stress & Cultivar & $\begin{array}{c}\text { Interaction } \\
\text { (stress X cultivar) }\end{array}$ \\
\hline \multirow{2}{*}{ Proline } & Leaves & $5.27^{*}$ & $0.00^{\mathrm{ns}}$ & $0.45^{\mathrm{ns}}$ \\
& Roots & $8.56^{* *}$ & $51.10^{* * *}$ & $0.58^{\mathrm{ns}}$ \\
\hline \multirow{2}{*}{ Solule sugars } & Leaves & $1.78^{\mathrm{ns}}$ & $25.79^{* * *}$ & $1.88^{\mathrm{ns}}$ \\
& Roots & $7.41^{* *}$ & & $5.98^{* *}$ \\
\hline
\end{tabular}

F- ratios are given for the main effects of the following levels of classification: stress intensity (i.e. $\mathrm{NaCl}$ concentration of stressing media) and cultivars and interaction between these levels of classification

${ }^{\mathrm{ns}}$ : not significant; $*$ : significant at $\mathrm{p}=0.05 ; * *$ : significant at $\mathrm{p}=0.01 ; * * *$ : significant at $\mathrm{p}=0.001$

Table 2: Results of 1-way analysis of variance for soluble proteins content of plants of two sugarcane varieties (CP65-357, salt-sensitive and CP66-346, salt-tolerant).

\begin{tabular}{lcccc} 
& \multicolumn{2}{c}{ CP65-357 } & \multicolumn{2}{c}{ CP66-346 } \\
& Leaves & Roots & Leaves & Roots \\
\hline Number of observations (n) & 12 & 12 & 12 & 12 \\
\hline Degree of freedom (df) & 3 & 3 & 3 & 3 \\
\hline F value & $4.42^{*}$ & $1.36^{\mathrm{ns}}$ & $2.15^{\mathrm{ns}}$ & $3.94^{\mathrm{ns}}$ \\
\hline Probability (p) & 0.0412 & 0.3239 & 0.1725 & 0.0537 \\
\hline Least Significant Difference (LSD) & 0.2446 & 0.4248 & 0.4655 & 0.3367 \\
\hline
\end{tabular}

F- ratios are given for the main effect of stress intensity (i.e. $\mathrm{NaCl}$ concentration of stressing media).

${ }^{\mathrm{n} s}$ : not-significant; $*$ : significant at $\mathrm{p}=0.05$ ).

\section{DISCUSSION}

Proline accumulation was frequently reported in salt-stressed plants (Misra and Saxena, 2009; Shafi et al., 2011). It was often considered as a compatible osmoregulator that can be involved in salt resistance mechanisms (Alvarez et al., 2003; Ehsanpour and Fatahian, 2003; Sakhanokho and Kelley, 2009). However, our results in sugarcane stressed plants showed that proline accumulation was similar in leaves of both cultivars while the salt-sensitive cultivar CP65-357 accumulated more proline in roots than the salt-tolerant cultivar CP66-346. We therefore, suggested that proline overproduction is a response to the osmotic stress due to the presence of salt in the plant culture medium. Our results tend to demonstrate that proline is not an indicator of salt tolerance in sugarcane plants and that the salt tolerance of cultivar CP66-346 was not related to proline accumulation. These results corroborated data reported in durum wheat (Almansouri et al., 1999), Acacia species (Yokota, 2003), and other sugarcane varieties (Wahid, 2004). However, other studies have reported that proline plays an important role in salt tolerance because tolerant genotypes accumulated more proline in leaves than salt sensitive genotypes. It is the case of Populus species (Watanabe et al., 
2000) and green gram (Misra and Gupta, 2005).

$\mathrm{NaCl}$ induced an increase in soluble sugars content both in leaves and in roots of both cultivars. Tolerant cultivar CP66-346 accumulated more soluble sugars than the sensitive CP65-357; this tendency is reversed in the roots. Salt stress effects result mainly in an increase of soluble sugars content in both leaves and the roots in many plants and the most tolerant cultivars accumulate more soluble sugars. Thus, Watanabe et al. (2000) reported that in the genus Populus, most saltresistant species accumulate more soluble sugars in leaves than sensitive ones in the presence of salt stress. Similar results were found in sunflower (Ashraf and Tufail, 1995). On the other hand, in Carthamus tinctorius, Ashraf and Fatima (1995) reported that two salt resistant accessions showed different responses: one of them accumulates more soluble sugars than the sensitive accessions, whereas the other accession accumulates similar amount of sugars than the sensitive accessions though it is more tolerant. Soluble sugars are known for their role in the osmoregulation in plants exposed to osmotic stress. According to Cram (1976), among the organic osmotica, sugars contribute with more than $50 \%$ to the total osmotic potential in glycophytes subjected to salt stress. The fact that, in our study, the most tolerant variety accumulates more soluble sugars in leaves indicate that soluble sugars play a key role in sugarcane salt tolerance. These results are in agreement with those reported by Wahid (2004) in sugarcane using other varieties.

Our results indicate that the content of soluble proteins increases in leaves and roots of tolerant cultivar CP66-346 whereas it decreases in the sensitive CP65-357; suggesting that these components could play a role in sugarcane plants salt tolerance. In general, salt stress results in a reduction of soluble proteins contents which are often due to an inhibition of their synthesis and/or the increase of their hydrolysis (Irigoyen et al., 1992). Thus Perez-Alfocea et al. (1994) reported that salinity caused a reduction in soluble proteins of tomato species independently from their level of salinity tolerance. In our previous study related to salt stress effects on sugarcane calli (Gandonou et al., 2011a), we have reported that soluble proteins content increased significantly in the salt-sensitive cultivar (CP65-357) while it decreased in the salt-tolerant one (NCo310). Probably, the increase observed in the tolerant cultivar CP66-346 was due either to a stimulation of the synthesis of existing proteins, or to the synthesis of novel proteins.

The present study revealed that proline appeared as a symptom of salt stress in sugarcane plants and was not an indicator of sugarcane plant salt tolerance. For the first time in sugarcane, we have demonstrated that soluble proteins synthesis could be stimulated by salt stress and that these proteins could play a role in salt tolerance. Complementary investigations are required to assess the molecular basis of salt tolerance mechanisms.

\section{ACKNOWLEDGEMENTS}

The authors thank Mr. Mohamed El Ghrassli (CTCS, Morocco) for plant material providing and Prof. Marcel Senou Department of Animal Production, Faculty of Agronomical Sciences, University of Abomey-Calavi (Benin) for the correction of the format draft of the manuscript. This research was supported by funds of " Programme d'Appui à la Recherche Scientifique (PARS AGRO 180)" from the "Ministère de l'Enseignement Supérieur, de la Formation des Cadres et de la Recherche Scientifique" of Morocco.

\section{REFERENCES}

Al-Karaki GN. 2000. Growth, water use efficiency and sodium and potassium acquisition by tomato cultivars grown under salt stress. J. Plant Nutr., 23(1): 18.

Almansouri M Kinet JM, Lutts S. 1999. Compared effects of sudden and progressive impositions of salt stress in 
three Durum wheat (Triticum durum Desf.) cultivars. J. Plant Physiol., 154: 743-752.

Alvarez I, Tomaro LM, Bernavides PM. 2003. Changes in polyamines, proline and ethylene in sunflower calluses treated with $\mathrm{NaCl}$. Plant Cell, Tissue and Organ Culture, 00: 1-9.

Ashraf M, Fatima H. 1995. Response of some salt tolerant and salt sensitive lines of safflower (Carthamus tinctorius L.). Acta Physiol. Plant., 17: 61-71.

Ashraf M, Tufail M. 1995. Variation in salinity tolerance in sunflower (Helianthus annuus L.). J. Agron. Soil Sci., 174: 351-362.

Cram WJ. 1976. Negative feedback regulation of transport in cells. The maintenance of turgor, volume and nutrient supply. In Encyclopedia of Plant Physiology, New Series (Vol. 2), Luttge U, Pitman MG (eds). Springer-Verlag: Berlin; 284-316.

Dasgan HY, Aktas H, Abak K, Cakmak I. 2002. Determination of screening techniques to salinity tolerance in tomatoes and investigation of genotype responses. Plant Science, 00: 1-9.

Ehsanpour AA, Fatahian N. 2003. Effects of salt and proline on Medicago sativa callus. Plant Cell, Tissue and Organ Culture, 73: 53-56.

Gandonou Ch, Abrini J, Idaomar M, Skali Senhaji N. 2005. Effects of $\mathrm{NaCl}$ on growth, ions and proline accumulation in sugarcane (Saccharum sp.) callus culture. Belgian Journal of Botany, 138(2): 173180.

Gandonou Ch, Errabii T, Abrini J, Idaomar M, Skali Senhaji N. 2006. Selection of callus cultures of sugarcane (Saccharum sp.) tolerant to $\mathrm{NaCl}$ and their response to salt stress. Plant Cell, Tissue and Organ Culture, 87: 9-16.

Gandonou CB, Bada F, Abrini J, Skali Senhaji N. 2011a. Implication of proline, soluble sugars and soluble proteins in sugarcane (Saccharum sp.) in vitro salt-tolerance. Rev. CAMES-Série A, 12(1): 46-51.
Gandonou CB, Gnancadja LS, Abrini J, Skali Senhaji N. 2011b. Salinity tolerance of some sugarcane (Saccharum sp.) cultivars in hydroponic medium. Sugar Cane International (in press).

Ghoulam C, Foursy A, Fares K. 2002. Effects of salt stress on growth, inorganic ions and proline accumulation in relation to osmotic adjustment in five sugar beet cultivars. Environmental and Experimental Botany, 47: 39-50.

Hoagland AR, Arnon DI. 1950. The water culture method of growing plants without soil. University of California Berkeley, Coll. Agric. Circ. No. 347.

Irigoyen JJ, Emerich DW, Sanchez-Diaz M. 1992. Water stress induced changes in concentrations of proline and total soluble sugars in nodulated alfalfa (Medicago sativa) plants. Physiol. Plant., 84: 55-60.

Lingle ES, Wiedenfeld PR, Irvine EJ. 2000. Sugarcane response to saline irrigation water. Journal of Plant Nutrition, 23(4): 469-486.

Lutts S, Kinet JM, Bouharmont J. 1996. Effects of various salts and of mannitol on ion and proline accumulation in relation to osmotic adjustment in rice (Oryza sativa L.) callus cultures. J. Plant Physiol., 149: 186-195.

Maas EV, Hoffman GJ. 1990. Crop salt tolerance- Current assessment. J. Irrig. Drain. Div. ASCE, 103 : 115-134.

Misra N, Gupta AK. 2005. Effect of salt stress on proline metabolism in two high yielding genotypes of green gram. Plant Science, 169(2): 331-339.

Misra N, Saxena P. 2009. Effect of salicylic acid on proline metabolism in lentil grown under salinity stress. Plant Science, 177(3): 181-189.

Munns R, Husain S, Rivelli AR, James RA, Condon AG, Lindsay MP, Lagudah AS, Schachtman DP, Hare RA. 2002. Avenues for increasing salt tolerance of crops, and the role of physiologically 
based selection traits. Plant and Soil, 247: 93-105.

Munns R, James RA., Lauchli A. 2006. Approaches to increasing the salt tolerance of wheat and other cereals. $J$. Exp. Bot., 57: 1025-1043.

Murashige T, Skoog F. 1962. A revised medium for rapid growth and bioassays with tobacco tissue culture. Physiol. Plant., 15: 473-479.

Perez-Alfocea F, Santa-Cruz A, Guerrier G, Bolarin C. 1994. $\mathrm{NaCl}$ stress-induced organic solute changes on leaves and calli of Lycopersicon esculentum, $L$. pennellii and their interspecific hybrid. $J$. Plant Physiol., 143: 106-111.

Prajuabmon A, Theerakulpisut P, Kijwijan B, Muangsan N. 2009. In Vitro Investigation on Salt Tolerant Characteristics of Rice Seedlings (Oryza sativa L.). Research Journal of Agriculture and Biological Sciences, 5(4): 423-427.

Rozeff N. 1995. Sugarcane and salinity. Sugar Cane, 5: 8-19.

Sakhanokho HF, Kelley RY. 2009. Influence of salicylic acid on in vitro propagation and salt tolerance in Hibiscus acetosella and Hibiscus moscheutos (cv 'Luna
Red'). Afr. J. Biotechnol., 8(8): 14741481.

SAS Institute. 1992. SAS/STAT User's Guide (Vol. 1; Release 6.03). Edn. SAS Institute Inc. Cary. NC: USA.

Shafi M, Bakht J, Khan MJ, Khan MA, Raziuddin. 2011. Role of abscisic acid and proline in salinity tolerance of wheat genotypes. Pak. J. Bot., 43(2): 11111118.

Smirnoff N, Cumbes QJ. 1989. Hydroxyl radical scavenging activity of compatible solutes. Phytochem., 28: 1057-1060.

Wahid A. 2004. Analysis of toxic and osmotic effects of sodium chloride on leaf growth and economic yield of sugarcane. Bot. Bull. Acad. Sin., 45: 133-141.

Watanabe S, Kojima K, Ide Y, Sasaki S. 2000. Effects of saline and osmotic stress on proline and sugar accumulation in Populus euphratica in vitro. Plant Cell, Tissue and Organ Culture, 63: 199-206.

Yokota S. 2003. Relationship between salttolerance and proline accumulation in Australian acacia species. J. For. Res., 8: 89-93. 